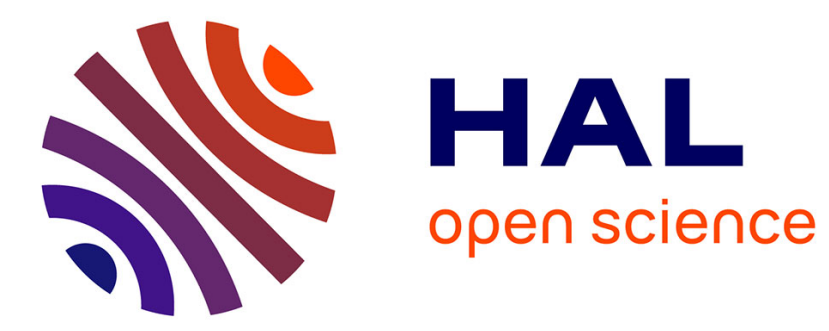

\title{
The Private Archives from Kanis Belonging to Anatolians
}

Cécile Michel

\section{To cite this version:}

Cécile Michel. The Private Archives from Kanis Belonging to Anatolians. Altorientalische Forschungen, 2011, 38, pp.94-115. halshs-01186438

\section{HAL Id: halshs-01186438 \\ https://shs.hal.science/halshs-01186438}

Submitted on 25 Aug 2015

HAL is a multi-disciplinary open access archive for the deposit and dissemination of scientific research documents, whether they are published or not. The documents may come from teaching and research institutions in France or abroad, or from public or private research centers.
L'archive ouverte pluridisciplinaire HAL, est destinée au dépôt et à la diffusion de documents scientifiques de niveau recherche, publiés ou non, émanant des établissements d'enseignement et de recherche français ou étrangers, des laboratoires publics ou privés. 
CÉCILe Michel*

\title{
The Private Archives from Kaniš Belonging to Anatolians
}

\begin{abstract}
This paper deals with 'Anatolian archives' from Kültepe, i.e. groups of tablets written in the Old Assyrian dialect but belonging to Anatolians. It is possible to trace their provenience and sometimes to identify the names of their owners. An analysis of the tablets' shapes, signs, syntax and grammar as well as the contents of some of these documents allow one to characterize them as tablets written by Anatolians.
\end{abstract}

Keywords: Old Assyrian, kärum Kaniš, Anatolian archives, signs, scribe.

During the Old Assyrian period Assyrians and local people lived together, along with other foreign merchants, in the lower town of Kaniš and in several other Anatolian towns. Among the 22,500 cuneiform tablets written in the Old Assyrian dialect discovered at Kültepe, a few groups of documents belonging to Anatolians show that these local inhabitants adopted cuneiform writing and the Old Assyrian dialect for their own purposes without attempting to adapt the writing system to their own language, as did the Hittites and the Hurrians centuries later.

In the following pages the expression 'Anatolian archive' thus refers to tablets written in the Old Assyrian dialect with Old Assyrian cuneiform signs, but composed or commissioned by an Anatolian individual and belonging to Anatolians. Most of the Anatolian archives from Kültepe are still unpublished, but excavation reports sometimes indicate houses in which such archives were found as well as the names of their owners, and these houses were located within the merchants' district. Comparison of the categories and contents of the available tablets belonging to Anatolians with documents belonging to Assyrians suggests limited use of writing by Anatolians, whereby the study of the characteristics of the Old Anatolian written corpus, such as the shape of the tablets, the signs, the writing of some personal names, syntax and grammar, can be instructive. The results allow one to identify and depict the owners of the Anatolian archives and the scribes of their tablets.

* ArScAn-Histoire et archéologie de l'Orient Cunéiforme, CNRS, Maison René-Ginouvès, Archéologie et Ethnologie, Nanterre. I wish to express my warmest thanks to Marie-Henriette Gates for correcting the English text. 


\section{Inventory of the Anatolian archives}

Up to the present, ca. 22,750 documents written in the Old Assyrian dialect have been recovered, of which 22,500 were found at Kanis.. ${ }^{1}$ Only 41 tablets were unearthed on the upper mound, while the great majority, 22,460 texts, come from the houses of merchants settled in the lower town. Most of the 4,800 tablets discovered before the official excavations, which started in 1948, are published, while of the 17,700 tablets unearthed during the official Turkish excavations only a thousand have been published so far. Thus only about $25 \%$ of the texts discovered at Kültepe have been published, and this study can therefore only offer some initial insights into the topic.

\subsection{Houses in Kaniš belonging to Anatolians}

The few tablets found on the upper mound are not taken into account here, because they were dispersed in several buildings. ${ }^{2}$ It is almost impossible, for the moment, to estimate the proportion of Kültepe documents from the lower city belonging to Anatolians vs. those belonging to Assyrians, but in general, the number of Anatolian archives seems to be quite small.

To gain a general picture of the Anatolian archives, one must distinguish between $k \bar{a} r u m$ level II and level Ib. This classification is complicated, since it is now clear from the eponym lists that only three years separated the two levels (Günbattı 2008). Moreover, the archaeological dating of texts is far from precise. ${ }^{3}$ The available archaeological data for level II are much more detailed than for level Ib. T. Özgüç (1948: 111; 1949: 114; 1959: 81; 1964: 27; 1986: 1-15; 2003: 100-101) published full reports, including some plans, of the excavations in the lower city that took place from 1948 to 1959 and from 1959 to 1983.

According to T. Özgüç (1959: XXII) about a hundred separate archives were found in level II. During the first decades of excavations, K. Balkan, epigrapher of the site together with E. Bilgiç, was reading the texts in order to identify some of the archive owners. Later, the archives of Šuppiahšu were identified by L. Matouš.

In the south-eastern quarter of squares A-Z/5-30, several archives belonging to Anatolians were found (Fig. 1):

${ }^{1}$ Michel (2003:V-VII) updated in Michel (2006: 436) and Michel (2011b:396).

2 The citadel produced only 41 tablets, attributed to levels 8 and 7; see Donbaz (1998); Michel (2003: 115-116; 2006: 444; 2011b); T. Özgüç (1999: 93, 103, 114). These documents are contemporaneous with kārum levels II and Ib. Several texts, e.g. Kt n/t 2100 (adoption) and Kt y/t 4 (loan in cereals; AKT 1 79), deal with transactions between Anatolians.

3 See the discussion by Kryszat (2008b: 159-165) about the first group of texts from 1962 (Kt n/k). Balkan $(1955: 65, n .8)$ reckons that 10 of the 20 tablets attributed to level Ib from the excavations of 1949 and 1954 belong in fact to level II. One noteworthy characteristic of the Ib tablets is the presence of seal impressions on the tablet itself, which contrasts with the impressions from kārum level II, which are on the envelopes (see for example Kt $\mathrm{j} / \mathrm{k} 625$ edited by Donbaz 1989:84,97). 


\begin{tabular}{|l|l|}
\hline Square & Owner of the house (year excavated) \\
\hline N/21 & Sarnikan \\
T-U/25 & Galulu \\
U-V/22 & Šarabunuwa (1955) \\
U-V/23-24 & Šakdunuwa \\
Y-Z/26-27 & Peruwa (1951;1954) \\
\hline
\end{tabular}

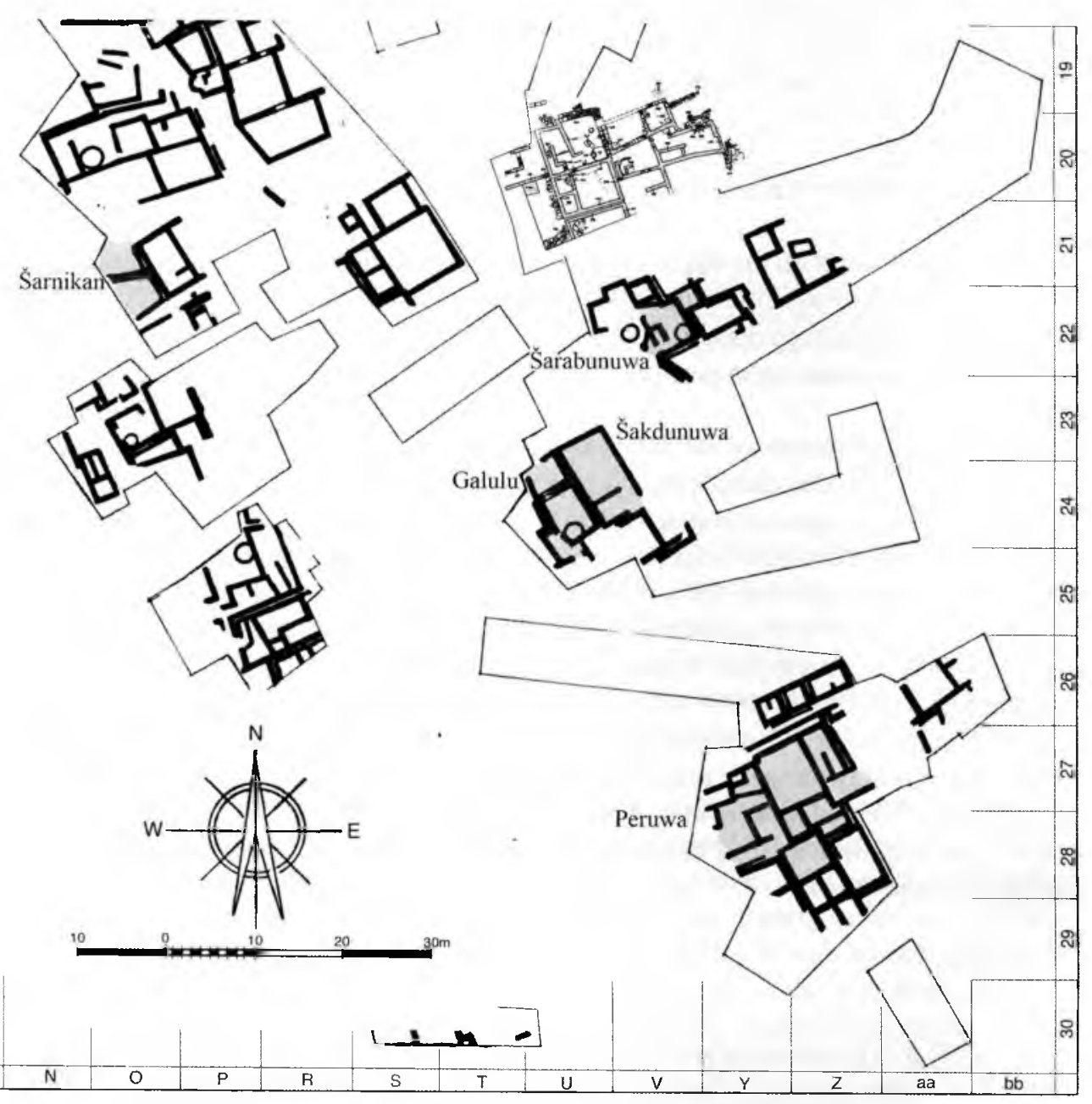

Fig. 1: Southeastern district of kârum level II with houses belonging to Anatolians. 
Other houses in this area were identified as belonging to Assyrian merchants such as Tāa-ahum, Alāhum (1950) and Aššur-emūqï. ${ }^{4}$

In the north-western quarter, west of the area excavated by B. Hrozny, who found the archives of Pūšu-kēn and Imdīlum in G-I/9-10 in 1925 (Hrozný 1927), it was revealed that area A-G/8-12 had been inhabited mainly by Assyrians, some of them well known, such as Laqēpum and Adad-ṣulūlī (1948). To the east of Hrozný's excavations was a mixed residential sector with houses belonging to Anatolians and Assyrians (dated to levels II and $\mathrm{Ib}$ ). Unfortunately, the names of most of the Anatolian inhabitants of this area, except Šppiahšu, are unknown (Fig. 2). ${ }^{5}$

These plans are far from complete. The entire area has now been excavated and seems to have been densely inhabited, as suggested, e.g., by the remains uncovered in area LV-LX/125-130, excavated mainly during the first half of the 1990s. ${ }^{6}$

Tablets from $k \bar{a}$ rum level Ib are quite rare, totalling as of the year 2000 only some 340 tablets (T. Özgüç 1986: 17-21). In 2001 archaeologists exposed a large house from this level containing a further 143 texts, including an eponym list and a letter of king Hurmeli (Günbatt1 2005). Apart from the eponym list (KEL G; Günbatt1 2008) the only text discovered in 2001 already published belongs to the heirs of Salim-Aššur, an Assyrian merchant. ${ }^{7}$

\subsubsection{Suppiahšu's house}

The house of Suppiahšu, excavated in 1959 (Kt k/k) in area M-N/11-13, was one of the biggest of level II with its $130 \mathrm{~m}^{2}$ and 8 rooms (Fig. 3). Rooms $1-3$ were added to the original five, perhaps once the owner had become wealthy. ${ }^{8} \mathrm{~A}$ staircase from room 1 led to a second floor, where the family slept. Room 3 had a very large oven, $2.40 \mathrm{~m}$. in diameter. Rooms 4 and 5 contained several pots, a silo and a hearth on a platform. Rooms 6 to 8 were used as storerooms. The smallest one, room 8, divided in two parts by a partition, was a kind of cellar reached by stepladder and was filled with stacked vessels. According to T. Özgüç (1986: 10; see also pls. 34, 2 and 36,36), 'The small archive of Suppiahšu, consisting of tablets and unopened envelopes, was found in this room on the floor near the pottery ... It is clear that the tablets, which were found on the floor and along the base of the walls, had fallen from shelves at the time of the conflagration. Archives are found to have been stored in pots, baskets and boxes on shelves, and on straw matting in a room corner.'

${ }^{4}$ I have tried to reconstruct an incomplete plan comprising excavated houses in squares $\mathrm{A}-\mathrm{Z} / 5-30$, which correspond to only part of the excavated area. This plan of $k \bar{a}$ rum II has been reconstructed according to various publications of $T$. Özgüç (see above). F. Kulakoğlu gave me a plan including squares LV-LX/125-128; may he receive my warmest thanks. This area is now better known by a plan published by Kulakoğlu (2010:45).

5 T. Özgüç (1964:33-34).

6 Excavations in 1991-1993: Elamma (1991) and Alāhum (1993), sons of Iddin-Sîn; Kuliya (1992), son of Alābum, messenger of the kārum; Amurru-bāni? (1992). The two houses inhabited by Alāhum, son of Iddin-Sîn, and his son Ašsur-taklāku, unearthed in 1993, were much destroyed; for a plan of this area, see Michel (2008c: 55).

7 Text Kt 01/k 325, published by Albayrak (2004).

8 T. Özgüç (1959: XXII) provides a list of owners of kārum II houses, including Šuppiahšu, and analyzes his house (T. Özgüç 1964: 33-34, figs. 3-5 and 1986; 9-10, 117, fig. 16a-b and plan 4). 


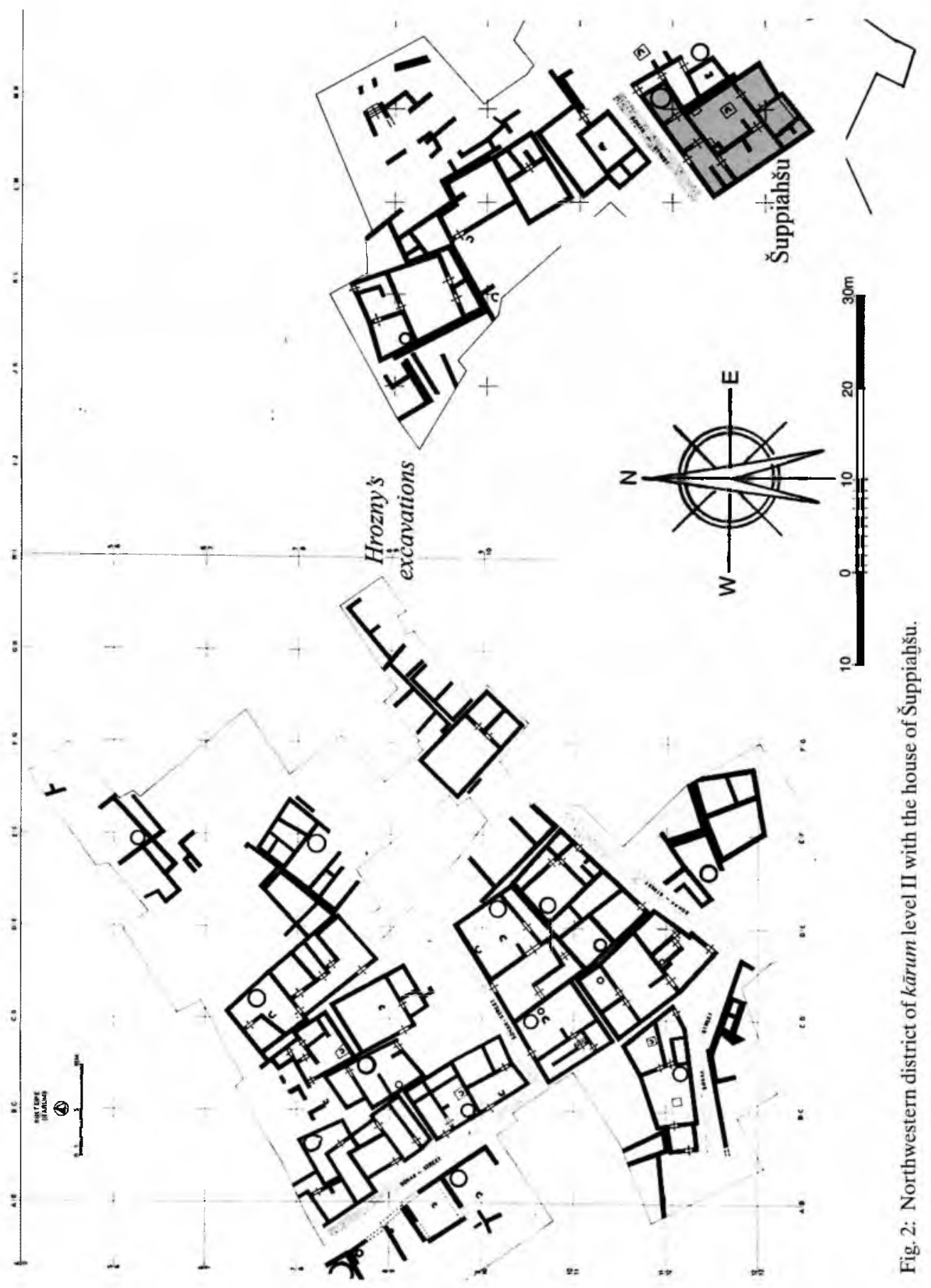



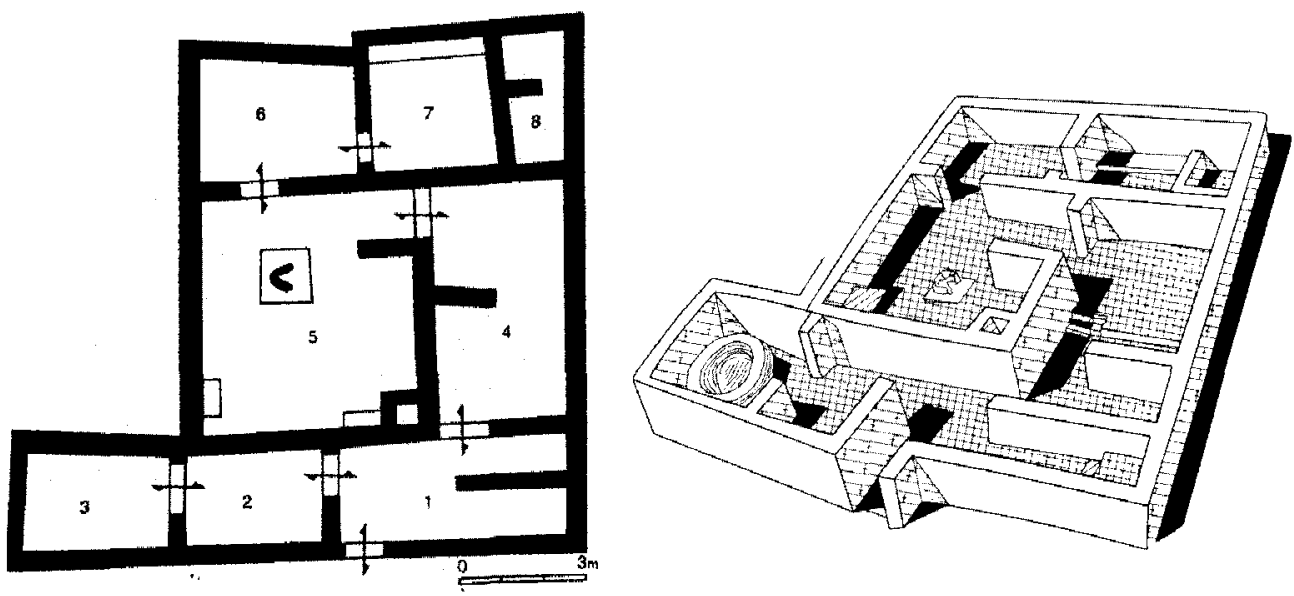

Fig. 3: The house of Šuppiaḩ̌su according to T. Özgüç (2003; 85-86).

\subsubsection{Peruwa's house}

In 1951 archaeologists working in area $\mathrm{Y}-\mathrm{Z} / 28$ found a small three-room house $(7.5 \times$ $4.5 \mathrm{~m}$..$^{9}$ In the north-western corner of the large room, identified later as the courtyard, they discovered 64 tablets, fragments and unopened envelopes arranged in two baskets. On the 43 envelopes N. Özgüç counted 85 different seal imprints, among which 60 belonged to local people. The owner of the archive was Peruwa.

Work continued in this area in 1954, extending Peruwa's house substantially (T. Özgüç 1959: 92-94 and fig. 50). It too can be counted among the largest houses of level II, with 14 rooms distributed over $224 \mathrm{~m}^{2}$ (Fig. 4). In addition to the tablets unearthed in 1951 in the courtyard (room 1), more unopened envelopes were found in a small cubicle, room 2 , and in a basement, room 12 .

\subsection{Status of publication of the Anatolian archives}

Most of the Anatolian archives unfortunately remain unpublished, and the date of some of them is much debated. Among the texts from the regular excavations of level II about ten Anatolian archives have been recognized.

The 64 documents unearthed in $1951(\mathrm{Kt} \mathrm{d} / \mathrm{k})$ in the house of Peruwa were assigned to K. Balkan, but he published only four of them, while Kienast published one further text. ${ }^{10}$

9 According to a preliminary report of the 1951 excavations published two years later (N. Özgüç 1953: 289-305), that season was conducted by N. Özgüç while her husband was in Great Britain.

${ }^{10} \mathrm{Kt}$ d/k 5 (Balkan 1967:408,n. 1); Kt d/k 19 (id. 1974:35); Kt d/k 28 (id. 1979:52); Kt d/k 48 (id. 1974:35); Kt d/k 29 (Kienast 2008: 46-47). During my first stay in Ankara, in July 1991, E. Bilgiç allowed me to work on this group of texts, and the data presented in this paper are based on my readings of the entire 


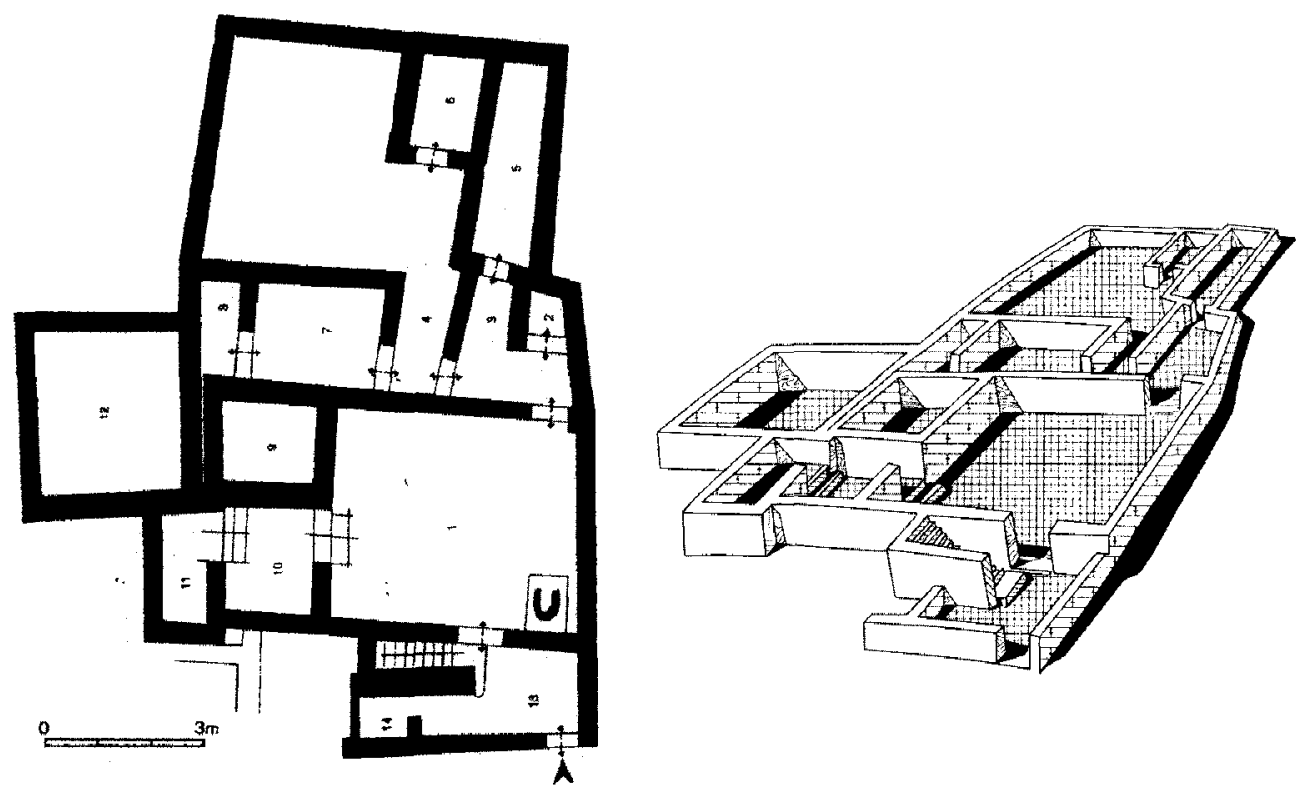

Fig. 4: The house of Peruwa according to T. Özgüç (2003:84-85).

A substantial part of the 196 documents discovered in $1954(\mathrm{Kt} \mathrm{f} / \mathrm{k})$ belonged to the same merchant and are still unpublished except for two texts. ${ }^{11}$ At least six other tablets belonging to a man called Peruwa, were found in $1950(\mathrm{Kt} \mathrm{c} / \mathrm{k})$ and have been published recently. ${ }^{12}$

A small archive containing 5 texts belonging to a certain Sarnikan, son of Arruba, was discovered in $1953(\mathrm{Kt} \mathrm{e} / \mathrm{k}){ }^{13}$

An archive belonging to one Sarabunuwa was excavated in $1955(\mathrm{Kt} \mathrm{g} / \mathrm{k})$, none of which has been published yet. The first 17 tablets ( $\mathrm{Kt} \mathrm{g} / \mathrm{k} \mathrm{1-17)}$ are loan contracts preserved with their envelopes, but it is not known how many of the 413 tablets and envelopes unearthed in 1955 belong to Sarabunuwa. ${ }^{14}$

archive. My transcriptions have been made available to all colleagues from Europe and Turkey specializing in the Old Assyrian period, and lines of several important texts have been cited in various articles (including the publication of $\mathrm{Kt} \mathrm{d} / \mathrm{k} 29$ by Kienast 2008 ).

11 These texts were deciphered by L. Umur, a PhD student at Istanbul University, who later left the field. K. Balkan published two loan contracts from this year dealing with Anatolians, one belonging to Peruwa (Kt f/k 120; Balkan 1979:56), the other to Šakdunuwa (Kt f/k 62;id. 1974:38).

$12 \mathrm{Kt} \mathrm{c/k} \mathrm{1634,1635,} \mathrm{1637,} \mathrm{1639,} 1641$ (Albayrak 2005) and Kt c/k 1642 (Albayrak 2007). The latter, concerning the sale of a plot of land, does not mention Peruwa's name.

13 Çayır (2004:46) wrongly states that these documents were discovered in 1952, the only year since 1948 during which there was no archaeological campaign at Kültepe. Most of the texts found in 1953 (up to number 152) belong to Aššr-emūqī; see Esen $(2001 ; 2002)$.

${ }^{14}$ For references to published lines, see Michel (2003: 77-78; 2006: 439; 2011b). Texts bearing a number higher than 100 seem to belong to one or more Assyrian archives. 
A small archive of Šuppiahš̌u found in $1959(\mathrm{Kt} \mathrm{k} / \mathrm{k})$ is still unpublished. ${ }^{15}$

In 1962 were discovered 2,158 tablets, fragments and envelopes, including 7 dealing with the business of Ašet, son of Arurubaš, alahhinnum of Dataša. ${ }^{16}$ These texts seem to date to the very end of $k \bar{a} r u m$ level II. ${ }^{17}$

The archives of Assyrian and Anatolian merchants unearthed in 1963 were found mixed together and are supposed to come from the same building. ${ }^{18}$ Among the Assyrian owners are the merchants Aššur-idī, son of Agua, Iddin-Sîn and Ușur-ša-Ištar. Among the tablets belonging to Anatolians are 7 documents from a woman's archive, Madawada (Albayrak 1998: 1-14). Other Anatolian names do not seem to be linked to a specific archive. ${ }^{19}$

In many archives are found some single texts dealing only with Anatolian names, but this does not necessarily imply that the whole archive would have belonged to an Anatolian family. Among the group of tablets uncovered in 1987, for example, are contracts mentioning only Anatolian names, though others clearly belong to Assyrians (Hecker 1997). ${ }^{20} \mathrm{At}$ least three loan contracts belonging to Šiwašmi, priest of the deity Higiša, were excavated in 1988 and 1989.21

Among the tablets uncovered before 1948 there are also documents belonging to Anatolians. Some were edited by Eisser and Lewy (1930/1935) in their study of Old Assyrian legal documents, including mainly family contracts, others by Kienast (1984: nos. 10-11,13, $15-17,20-22,25-26,28-29,32,34,37)$ in his treatment of sale contracts. Dercksen edited those dealing with a selection of Anatolian institutions, ${ }^{22}$ and the documents relating to Enišaru's family and business were studied by Veenhof. ${ }^{23}$

Of the 480 tablets from kārum level Ib a significant proportion belongs to Anatolian archives. ${ }^{24}$ A few have been edited by Donbaz $(1989 ; 1990 ; 1993 ; 1999 ; 2001 ; 2004 a)$, but

15 Šuppiahšu's archive must have been quite small, since only 5 of the 121 documents unearthed in 1959 mention his name (Kt k/k 31: 1, 8; 33: 12; 34: 1; 35a: 12; 35b: 6; 36: 17, 18). T. Özgüç (1964: 32) reports ca. 800 tablets for this archive, but there seems perhaps to be some confusion with another group of texts.

${ }^{16} \mathrm{Kt} \mathrm{n} / \mathrm{k} 71-77$, published by Donbaz (1988).

17 According to Kryszat (2008b: 159-161) this name is a homonym of the rabi mahisim mentioned in $\mathrm{Kt} \mathrm{n} / \mathrm{k} 32,8,34$, dated to kärum level Ib.

18 Building B-D/11-12, room 2. The texts were published by Albayrak (2006) in AKT 4; see also Veenhof (2009).

${ }^{19}$ E.g., Kt o/k 52, dealing with the transfer of 4 fields and a garden by Kubidahšu to Ašu'ad, persons not mentioned elsewhere in the archive.

20) A certain Kikarša(n) occurs several times (Kt 87/k 39: 1, 8; Kt 87/k 126:12, 18, 21; Kt 87/k 266: 3;

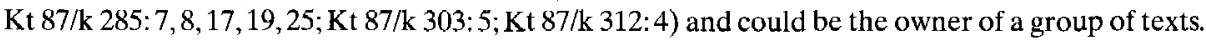

${ }^{21}$ Kt 88/k 1082, Kt 88/k 1087 and Kt 89/k 358; see Donbaz (1996); Dercksen (2008: 88). According to Kryszat (2004:177) it is a kärum level II archive.

${ }_{22}$ Dercksen (2004: 156-165): BIN 4 209; Prag I 568; Ka 1113; Münster 2432; Kay 294; SUP 1; VS 26 100; VS 26101 .

2.3 Veenhof (1978): CCT 5 49d; CCT 1 10b; TC 1 68;TC 3 327; ICK 1 129; Prag I 697; JCS 14, no. 12.

${ }^{24}$ Including at least the following: from 1949: Kt b/k 21;1953: Kt e/k 167; 1958: Kt j/k 625; 1959; Kt k/k 9-11, 14 (Donbaz 1989: 81-84); 1962: Kt n/k 11, 14, 31-32, 39 (Donbaz 1989; 2008; Kryszat 2008b); 1964: 10 tablets; 1965: 10 tablets, including Kt r/k 15, 19 (Donbaz 1989: 78-81); 1967: 15 tablets, including Kt ş/k 3, 10; 1968: 2 tablets; 1973: Kt 73/k 74, 76, 78; 1987: Kt 87/k 39 (Donbaz 1993: 146-148); 1988: Kt 88/k 713 (Donbaz 1993: 145-146); 1989: 30 texts, including Kt 89/k 358-383 (Donbaz 1993); 
most are still unpublished. The owners of these documents, consisting of scattered texts rather than real archives, are therefore not yet known.

\section{Contents of some Anatolian archives}

There are at least three difficulties in studying the contents of Anatolian archives. First, as noted, they are for the most part still unpublished. Second, there are many homonyms in the Anatolian onomasticon; several merchants, for example, were called Peruwa (see below). Third, the number of tablets discovered in the houses of Anatolian merchants is always very small compared to the numbers found in the houses of Assyrians. Nevertheless, it is possible to eke an idea of their contents from a sample of Anatolian archives.

\subsection{Small Anatolian archives of kārum level II and their contents}

Among the few published Anatolian archives from level II are found the following groups:

\begin{tabular}{|l|l|l|l|l|l|}
\hline $\begin{array}{l}\text { Year }(\mathrm{k}): \\
\text { no. of texts }\end{array}$ & Owner & Witness & $\begin{array}{l}\text { Name } \\
\text { not cited }\end{array}$ & $\begin{array}{l}\text { Loan } \\
\text { contracts } \\
\text { (creditor) }\end{array}$ & $\begin{array}{l}\text { Purchase and } \\
\text { other contracts }\end{array}$ \\
\hline $1950(\mathrm{c} / \mathrm{k}): 6^{25}$ & $\begin{array}{l}\text { Peruwa, } \\
\text { s. Şuppibra }\end{array}$ & 1 & 2 & 2 & 1 \\
\hline $1953(\mathrm{e} / \mathrm{k}): 5^{26}$ & Šarnikan & & & 4 & 1 (slave) \\
\hline $1962(\mathrm{n} / \mathrm{k}): 7^{27}$ & $\begin{array}{l}\text { Ǎset, } \\
\text { s. Arurubaš }\end{array}$ & 1 & & 3 & $\begin{array}{l}2 \text { (slave) } \\
1 \text { (house) }\end{array}$ \\
\hline $1963(\mathrm{o} / \mathrm{k}): 7^{28}$ & f Madawada & & & 6 & 1 (slave) \\
\hline
\end{tabular}

These archives rarely deal with long-distance trade.

\subsection{Peruwa's archive unearthed in 1951}

The 64 tablets unearthed in 1951, 45 of which were preserved together with their envelopes, belong to the archives of Peruwa. ${ }^{29}$ The name Peruwa is found in 48 of them, while the others concern predominantly Assyrians. These 48 texts comprise the following:

1999: Kt 99/k 138-139; 2001: 143 tablets. To these one should add the following tablets uncovered before 1948: Eisser and Lewy (1930/1935: nos. 3, 189, 276); Kienast (1984: no. 18); Dercksen (2004: 172-174 [TC 1 122; TC 3214]).

25 Albayrak (2005: 101).

${ }^{26}$ Çayır (2004).

${ }^{27}$ Donbaz (1988).

28 Albayrak (1998).

29 The seal impressions on the envelopes were published by N. Özgüç (2006:59-92). 
- 32 loan contracts concerning silver and grain in which Peruwa is creditor;

- 2 loan receipts in which Peruwa is creditor;

-6 purchases of one or two fields by Peruwa;

- 1 purchase of a house by Peruwa;

- 4 purchases of a slave by Peruwa;

- 1 marriage contract in which Peruwa is witness;

- 1 letter sent by an Assyrian to two Assyrians and Peruwa;

- 1 fragment.

\subsection{Contents of the Anatolian archives and comparison with the Assyrian archives}

Anatolian archives contain predominantly loan and purchase contracts as well as some contracts concerning family matters. They are quite different from what can be reconstructed of the Assyrian archives, ${ }^{30}$ which contain the following groups of texts:

- letters received from merchants in Aššur or in other Assyrian settlement in Anatolia;

- loan contracts, judicial documents, trial proceedings and verdicts and various familial and commercial contracts;

- lists, private notices, memoranda, etc.

Very few letters were found in the Anatolian archives, since their native owners did not need to maintain contact with families and colleagues living in Aššur, as did the Assyrians. There are two categories of letters received by Anatolians:

- those dealing with trade, usually sent by Assyrian colleagues; a single letter (Kt d/k 2), found in 1951, was written by an Assyrian (Buzāzu) and addressed to Peruwa and to two Assyrians, Ab-šalim and Aššur-malik; .

- those mixing trade and matters concerning daily life written by Assyrians to their Anatolian wives (Michel 1997; 2008b).

The loan contracts owned by Anatolians are quite similar to those belonging to Assyrians, but are much more numerous as a proportion of the archives in which they were found. They concern silver and grain, and a default interest is noted. The debtors are generally Anatolian colleagues. The few documents mentioning loans to Assyrians concern significant amounts of silver, between 1 and 5 minas. The main difference concerns the calendar. The Assyrian loan contracts are usually dated by a week (hamuštum), a month and a year (eponym, limum), the deadline for the payment being given in weeks (Michel 2010a). The Anatolian loan contracts, in contrast, rarely use the Assyrian week and eponym system, preferring to indicate payment dates relating to seasonal events, such as festivals or agricultural activities (Veenhof 2008a:234-245; Michel 2010a). For example, the loan contracts of Peruwa unearthed in 1951 employ the following payment deadlines: harp $\bar{u}$, 'summer' 
(Kt d/k 9; 14; 18;21;22; 23; 26;28; 43; 45; 48), daš'ü, 'spring' (Kt d/k 30), ebūrum, 'harvest, crop' (Kt d/k 19), ana kubur ut tititim, 'when the grain is ripe' ( $\mathrm{Kt} \mathrm{d} / \mathrm{k} 44)$, qitip kirannim, 'the picking of the grapes' (Kt d/k 16), as well as festivals for Anna, the main god of Kanis $(\mathrm{Kt} \mathrm{d} / \mathrm{k} 35)$ and $\mathrm{Pa} / \mathrm{irka}(\mathrm{Kt} \mathrm{d} / \mathrm{k}$ 15). Occasionally the date of the transaction is related to an event such as 'when the prince enters the temple of Nipas' or 'when the prince leaves the temple of Nipas'. ${ }^{31}$ Alternatively, the payment date may be defined by a specified number of months (1 month: Kt d/k 13) or years (7 years: Kt d/k 17).

Some of Suppiahšu's loan contracts dealing with grain in the context of joint land ownership further state that the debtor must cultivate a field of a certain measure as part of the payment: ' 2 fields, his share (in a partnership), of 2 naruq surface (240 l.), (the debtor) will cultivate; the 6 jars $\left(180 \mathrm{l}\right.$.) of seeds are at his (expense), ${ }^{32}$

The purchase contracts, many of which have been studied by Kienast (1984), concern slaves, houses and land. While both Assyrians and Anatolians bought slaves and houses, the purchase of land was typically Anatolian. Among the tablets belonging to Peruwa ex-

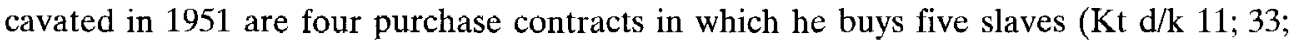
$41 ; 49)$, one text in which he pays for a house ( $\mathrm{Kt} \mathrm{d} / \mathrm{k} \mathrm{38}$ ), and six purchase contracts in which he buys seven fields (Kt d/k $6 ; 10 ; 27 ; 40 ; 42 ; 52)$, one of which includes a spring $(\mathrm{Kt} \mathrm{d} / \mathrm{k} 27)$. Some of these mention a possible claim involving land linked to a service obligation (tuzinnum; e.g. Kt d/k 11).

Anatolian archives also contain family contracts dealing with marriage and divorce, adoption, brotherhood and division of estate, revealing traditions that differ from those of the Assyrian family contracts. The few marriage and divorce contracts suggest, for example, that Anatolian marriage was exclusively monogamous and that man and woman enjoyed equal property rights (Michel 2010b; 2011a). A marriage contract found among the archives unearthed in 1951 concerns an Assyrian merchant and an Anatolian woman, Peruwa acting as a witness (Kt d/k 29). The great majority of marriage and divorce contracts deal with mixed couples. In fact, the Assyrian merchants were allowed to take a second wife in Anatolia and, after several years in Anatolia, could decide to go back to Ašsur. They had to formalize their separation from their Anatolian wife by an official document detailing the woman's divorce compensation and decisions concerning the children (Michel 2008b:222-225). Such legal dôcuments pertaining to Anatolians could be concluded by an oath involving Assyrian and Anatolian gods (e.g. Prag I 651 or ICK 132).

Most of the family contracts dealing with Anatolians are dated to kärum level Ib and are issued under the jurisdiction (ina qāte ) of the local ruler and the rabi simmiltim, who usually corresponds to the crown prince (Veenhof 2003: 454; Dercksen 2004: 140-145, 168, 172-173). Once a case was settled, raising a renewed claim could lead to a fine and even a death penalty (e.g. Kt $\mathrm{j} / \mathrm{k} 625$ or $\mathrm{Kt} \mathrm{k} / \mathrm{k} 1$ ). Also dated to kärum $\mathrm{Ib}$ are contracts registering the formation of joint property ownership between natural or adopted brothers working

${ }^{31} \mathrm{Kt} \mathrm{d} / \mathrm{k} 17$ and $\mathrm{Kt} \mathrm{d} / \mathrm{k} 46$. Anatolian contracts of level Ib were notarized (iqqāti), and thus dated, by the king and crown prince.

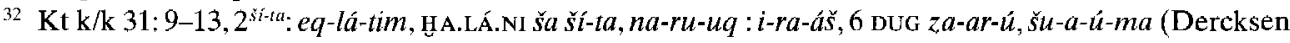
2008:142-143). 
for and in an estate under the supervision of their father and mother $(a t h \bar{u}) \cdot{ }^{33}$ Others deal with division of property among heirs. Some family contracts mention service obligations linked to the ownership of a 'house of the king', such as arhälum and unuššum (Dercksen 2004).

\section{Characteristics of the Anatolian corpus}

There are at least two problems in distinguishing between tablets written by Anatolians and those written by Assyrians. The first concerns the connection between the persons mentioned in a document and the text's author. Must a tablet dealing with Anatolian matters have been written by an Anatolian scribe? Second, Anatolian archives are very few in comparison to the enormous quantity of documents unearthed in the lower city, and they are not equally distributed between kärum levels II and Ib. Anatolian archives represent less than $5 \%$ of the total number of tablets from level II, while they constitute at least $25 \%$ of those from level Ib. Thus, some of the characteristics said to be typical of the kārum Ib tablets may in fact be attributable to Anatolian scribes.

\subsection{Tablets, signs and spelling}

Tablets belonging to Anatolians seem, in general, less carefully shaped than Assyrian ones. They are approximately square or rectangular, with rounded corners, Fig. 5 illustrating types of tablets dating to both kārum levels. Kt $93 / \mathrm{k} 473$ is a level II tablet written by the well-trained Assyrian merchant Aššr-taklāku, owner of the archives unearthed in 1993. He produced documents with a very small and tight script enabling him to write at least 40 lines on a tablet less than $5 \mathrm{~cm}$ high. Kt $88 / \mathrm{k} 990$ is a level II slave purchase contract belonging to an Anatolian man. Its writing is much bigger and more widely spaced. Kt $\mathrm{n} / \mathrm{k} 27$ is a level Ib judicial report dealing with Assyrians and has a regular script compared to that of $\mathrm{Kt} 89 / \mathrm{k} 365$, a legal decision concerning a house that was the subject of a dispute among Anatolians. However, tablet shape and style are not always certain criteria according to which one can distinguish between documents written by Assyrians as opposed to those drafted by Anatolians, since Assyrians could also write tablets that are not well shaped and written, as may be seen in Kt 93/k 279, a letter sent by Ištar-wēdāku to Ǎšsur-taklāku.

The signs written by Assyrians usually employ more numerous but also more regularly placed wedges, and a vertical that is supposed to terminate at a horizontal, or vice versa, generally does so quite precisely. Wedges forming a sign are placed more tightly together in texts referring to Assyrians, more loosely in tablets belonging to Anatolians. Once again, this distinction can also differentiate an educated merchant or a scribe from a person who had learned the basic principles of writing but had not received formal training.

Kryszat (2008a) lists two categories of signs that distinguish documents produced by educated merchants or scribes. Group A comprises those most often used (90\%) as well as

${ }^{33}$ Kt e/k 167; Prag. I 837; KTK 33. See Dercksen (2004: 143-144) and Veenhof (1977: 145). 
Level II tablets

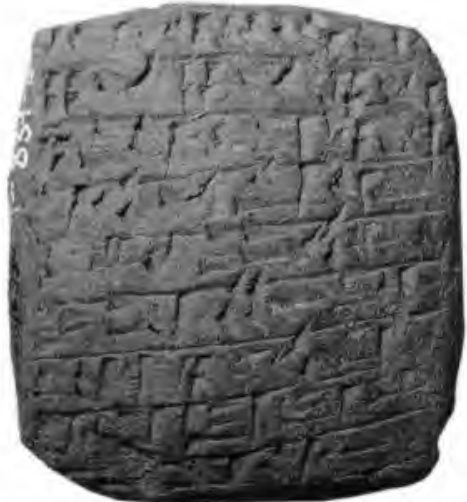

Anatolian: Kt 88/k 990

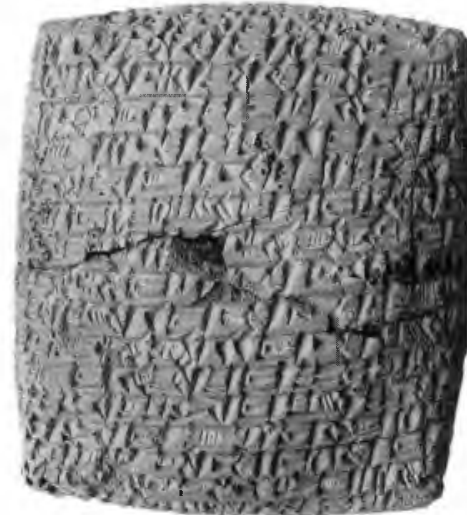

Assyrian: Kt 93/k 473

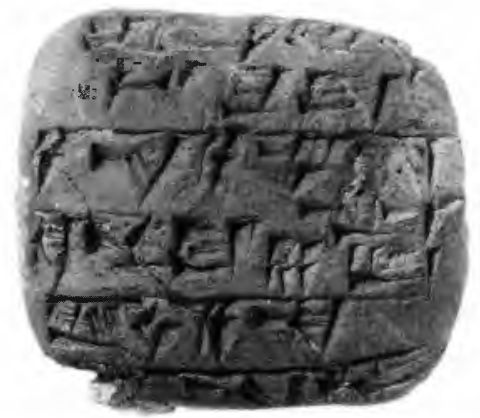

Assyrian: K $93 / \mathrm{k} 279$

Level Ib tablets

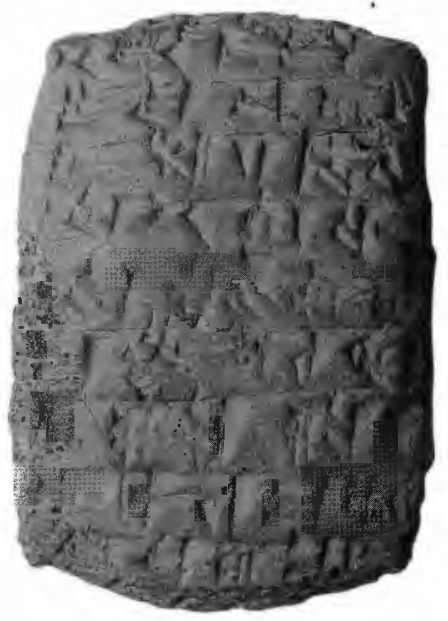

Anatolian: Kt 89/k 365

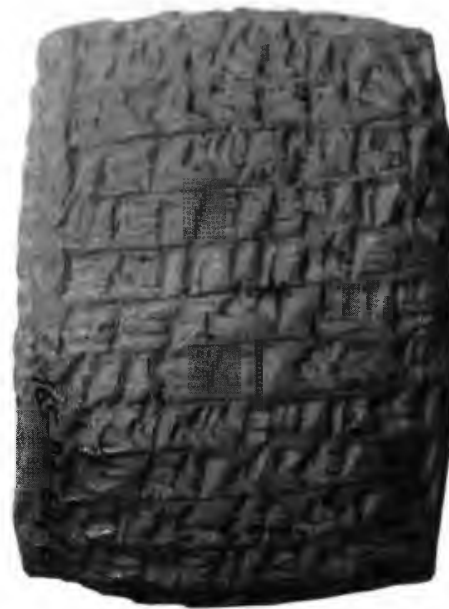

Assyrian: Kt n/k 27

Fig. 5: Tablet types of kârum levels II and Ib. 
simple signs, such as lá, $t i ́$ and $a ́ b$, while group B (10\%) contains more elaborate signs, such as $l a, t i$ and $a b$. Group B signs disappear during the reign of Narām-Sîn (ca. 1872 B.C.). According to Kryszat, none of the texts written by Anatolians uses the signs of Group B. But, as mentioned, the majority of Anatolian documents date to level $\mathrm{Ib}$, a period during which Group B signs were no longer in use.

It is also possible to identify a number of peculiarities in the Anatolian documents that suggest that their scribes were writing in a language other than their mother tongue: ${ }^{34}$

- Some vowels that are seldom written plene in normal Old Assyrian orthography are written plene, especially in proper names, but also in some nouns, even extending to the final vowel of conjugated verbs, ${ }^{35}$

- Duplicated signs or words, ${ }^{36}$

- Unusual syllabic sequences; ${ }^{37}$

- Anatolian knowledge of ideograms seems to be quite poor; one finds, e.g., wa-ah-ri-im for usual ITI in the loan contract Kt d/k 22b:18;

- As Kryszat (2008a: 235-236) has noted, Anatolian names are written with a final (nom. sg.) - $a s ̌$ by Anatolian scribes, but not by Assyrians. ${ }^{38}$

- The writing of Anatolian proper names is not fixed and vowels alternate between $a, u$ and $i,{ }^{39}$ but naturally such variation in the writing of Anatolian names can result from Assyrians failing to hear them correctly as well.

\subsection{Syntax and grammar}

There are several syntactical and grammatical peculiarities in the Anatolian documents as well. These have been listed in detail by Kienast (1984: 31-32), who noticed that, among 20 contracts dealing with Anatolians, only one contains no mistakes. Among the peculiarities one finds:

${ }^{34}$ Some of these have been previously observed by Dercksen (2007); Kienast (1984: 31-35); Kryszat (2008a).

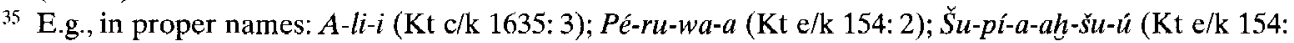
16); Lu-lu-lú (Kt d/k 13a: 1; Kt k/k 37a: 16); A-ši-e-et (Kt n/k 76: 12); Kà-lu-ú-a (Kt n/k 76: 8); in sub-

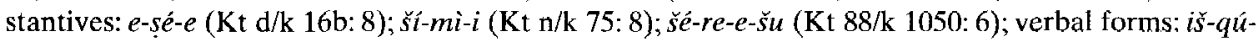

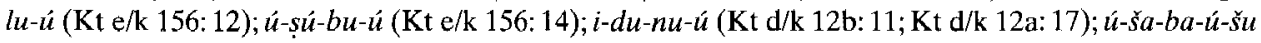
( $\mathrm{Kt} \mathrm{d} / \mathrm{k} 17 \mathrm{~b}: 14)$; such forms are less common in Assyrian texts.

36 E.g.: ša-tim ša-tim (Kt d/k 20a:9-10); i-tù-ru i-tù-ru (Kt d/k 42b: 12-13); IGI IGI (Kt k/k 10: 27); 1 ma-na KÙ.BABBAR, 1 ma-na KÙ.BABBAR (Kt r/k 19:14-15).

37 Ha-ra-am-id-nam (Kt e/k 155:3);Ki-kà-ar-áš-na-ah-šu (Kt d/k 9b:18; Kt d/k 9a:4).

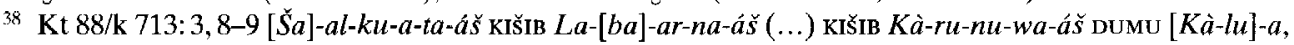
кIšIв Tù-ut-hi-li-áš (Donbaz 1993:145-146).

39 Pè-ru-a (Kt c/k 1634: 17), Pé-ru-wa (Kt c/k 1637:2), Pé-er-wa (Kt d/k 28b:6,17,19; Kt d/k 40b: 9, 16); Pí-ir-kà (Kt d/ 15b: 7-8; Kt d/k 15a: 16-17), Pár-kà (Kt n/k 168: 6); Iš-pì-nu-ma-an (Kt e/k 155: 2), [I] ̌̌-pu-nu-ma-an (Kt 88/k 90: 4); Š́-ik-ri-ú-ma-an (Kt d/k 52b:3), Ša-ak-ri-ú-ma-an (Kt 84/k 169:3); Ši-hu-ur-pí-a (Kt n/k 72:4), Šu-ha-ar-pi-a (Kt n/k 31:6), Šu-hu-ur-pi-a (Kt 89/k 376:2); Lu-li-ú (Kt k/k 37:3) for $L u-l u(\mathrm{Kt} \mathrm{80/k} \mathrm{25:3).}$ 
- Confusion of singular and plural forms, accusative and dative cases as well as feminine and masculine genders; ${ }^{40}$

- Omission of the conjunction $u$ between two nouns. ${ }^{41}$

Anatolians were not well trained in the scribal art and, while some mistakes can be regarded as conditioned by differences between the scribes' mother tongue and the language in which they were writing (gender confusion), others must be attributed simply to poor command of Akkadian (errors in number and case).

\section{Owners of the Anatolian archives and the authors of their documents}

Before trying to define who wrote the texts, an attempt should be made to identify the owners of the archives. This is not an easy task because the tablet finds from various loci are mixed, and there are many homonyms within both the Assyrian and the Anatolian communities.

\subsection{The owners of Anatolian archives}

Anatolian archive owners are, for the most part, wealthy, a fact confirmed, for example, by the large houses of Šppiahšu and Peruwa dating from kārum level II (see above). According to several loan and purchase contracts, some Anatolians owned many fields, and others strengthened their relationships with the Assyrians by way of mixed marriages. Thus, Enišaru, son of Kunsat gave his daughter as wife to an Assyrian named Laqepum, and there are many more such examples (Veenhof 1978; Michel 2008b). Other Anatolians had official or cultic functions in Kaniš (Veenhof 2008a: 230-233); thus, Šiwašmi, the priest of Higiša, loaned enormous amounts of grain to various groups of people on several occasions.

The case of Peruwa, son of Suppibra, whose archive was unearthed during the excavations in $1950(\mathrm{Kt} \mathrm{c} / \mathrm{k})$ and subsequently published by Albayrak (2005: 101; 2007:

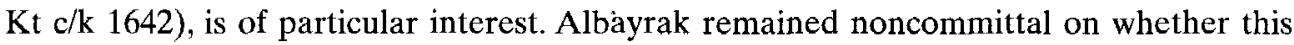
merchant should be considered identical to Peruwa, owner of the $1951(\mathrm{Kt} \mathrm{d} / \mathrm{k})$ archives and part of those from $1954(\mathrm{Kt} / \mathrm{k})$. Indeed, at least 20 individuals can be shown with reference to their differing fathers' names to have borne the name Peruwa. ${ }^{42}$ The owner

40 The latter distinction, of course, does not exist in Hittite or Luwian, which distinguish rather between animate and inanimate. Examples of singular instead of plural forms include: šál-mi-šu-un $\dot{u} i$-ni-šu$<n u>\hat{E}^{r i}-s ̌ u-<u n>(\mathrm{Kt} \mathrm{d} / \mathrm{k} 17 \mathrm{e}: 18-19)$; sál-mi-šu-<nu> ù ki-ni-šu-nu (Kt d/k 19a: 17-18); gender confusion: a woman called 'son of' (AAA 1/3 8: Simnuman DUMU.<MUNUS> Tatali), masculine and feminine suffixes confused (TC 3 214A ašar libbišu instead of as̆ar libbiša). In a dispute between two women (Kt c/k 1637) one finds confusion in number and gender: Tepulka u Šuppianika DUMU.munus (no plural) Kunuwan izzuzū (masc. instead of fem. form), bètam rebētam Šuppianika ilqe (masc. instead of fem.) bètam šaniam Tepulka talqe (here fem. is correct). See Dercksen (2007).

${ }^{41}$ E.g. Kt c/k 1639b: 16; Kt d/k 9b: 11; Kt d/k 34b:6; Kt j/k 625: 14-15.

42 There are several other Anatolian merchants named Peruwa mentioned in the archives unearthed in 1951: a son of Halkiašu (Kt d/k 16a: 1-2); son of Nakiahšan (Kt d/k 22a: 1-2; 22b: 20-21); son of Ka- 
of the 1951 archive is referred to as the chief shepherd in a loan contract in which he is creditor $(\mathrm{Kt} \mathrm{d} / \mathrm{k} 51)$. If one assumes that the marriage contract between Puzur-Šamaš and H ašušarnika found in 1951 was witnessed by the owner of 1951 and $1954(\mathrm{Kt} \mathrm{d} / \mathrm{k} 29)$, then he would be the same man whose archives were unearthed in 1950, since, according to the envelope of this contract (Kt d/k 29a: 1), his father's name is $\breve{S} u$-pè-e-eb-ra. Thus, Peruwa's archives would have contained perhaps more than 150 documents. He is known to have been active around Aššur eponym no. 96 (under the reign of Puzur-Aššur II) ${ }^{43}$ and to have loaned silver, barley and wheat to many individuals, even to a whole village. He was important enough to have his own standard measure. ${ }^{44}$ Peruwa seems to owe his wealth at least in part to his official position, as he seems to have received land from the king, to have purchased further fields as well, and finally, to have been able to produce far more crops than he needed.

The other Anatolian owners of archives also seem to have been very wealthy, and it appears reasonable to assume that only affluent persons needed to record their most important transactions. Not only Anatolian men but also women could own an archive, as witnessed by the tablet collection of a certain Madawada, published by Albayrak (1998).

\subsection{Authors of documents belonging to Anatolians}

There are criteria according to which authors of official documents belonging to Anatolians and those who wrote private texts can be distinguished.

\subsubsection{Authors of Anatolian official documents}

The Old Assyrian written dialect served as the diplomatic language between the Anatolian kingdoms, and it may be supposed that texts emanating from chancelleries were written by official scribes appointed by the palace. Only very few official Anatolian documents are published. Veenhof recently published a document in which the merchant Hannan-Nārum, son of Elālì, had taken up the function of scribe in Mamā (AKT 5 51:40-41), proposing that Hannan-Nārum served as scribe for the Assyrian community or in the service of the local palace (AKT 5, p. 161). The several copies of treaties between Anatolian and Assyrian authorities were clearly written by Assyrians. The scribe of the letter sent by Anum-Hirbi, king of Mama, to Waršama, king of Kaniš, is unknown (Kt g/t 35 = Michel 2001: no. 62, kārum Ib). Likely is Veenhof's (2008a: 48) suggestion that he was an Assyrian, the erasures,

piria (Kt d/k 34a: 8); and son of Mulua (Kt d/k 44a: 3). Another Peruwa, son of Hapuašu, appears as a witness in a text excavated in 1954 (Kt $\mathrm{f} / \mathrm{k}$ 59: 22-23). Further homonyms of Peruwa are found in other archives: son of Dada (CCT 1 33b: 15), son of Enna-Sîn (Prag I 478:27), son of Hamuria (ICK 1 27B: seal A), son of Hanu (Kt ş/k 10:3,18), son of Kanana (Prag I 674:5), son of Karunuwa (KKS 36A: 14; B: 14), son of Šadahšu (VS $26125: 19$ ), son of Šakriuman (Kt k/k 37b:13), son of Tarikuda (Kt v/k 152: 8), son of Walahšina (KTS $146 \mathrm{a}: 3,7)$, son of Zapali (Kt n/k 73:5).

${ }^{43} \mathrm{See} \mathrm{Kt} \mathrm{f} / \mathrm{k}$ 51, a loan contract belonging to Peruwa and dated to the eponym Kubiya, son of Ikkupiya, whereby the father's name is an error for Karriya (KEL 96; Veenhof 2003:34,53-55).

44 Ina karpitim ša Peruwa (Kt d/k 19b: 8-9). 
use of wrong signs, etc. being 'indications that the writer was an Assyrian trader, who knew very well how to handle the stylus, but who may have been less experienced in writing such a diplomatic letter and, not being a professional writer, may have made a few scribal mistakes (without somebody to correct him) and may have used "colloquial diction".,45 The local king might also have dictated his letter to a translator, who could thus be responsible for some of the errors. It is most probable that the less official letter sent by the ruler of Tuhpiya to an Assyrian merchant was also written by an Assyrian (Kt 85/k $87=$ Michel 2001: no.93).

\subsubsection{Authors of Anatolian private documents}

The Anatolian private archives are mainly composed of contracts. Unfortunately, contrary to the Old Babylonian tradition, scribes are very rarely mentioned among the witnesses in the Old Assyrian contracts. While there is therefore no explicit indication about the authors of documents, Kryszat (2008a: 234) has suggested that Anatolian contracts mentioning at least one Assyrian among the witnesses could have been written by him in his function as a scribe. Where no Assyrian is mentioned, the document would have been written by an Anatolian. He quotes as an example a tablet bearing no Assyrian name and showing typical features of some Anatolian written texts, such as the ending of personal names with a final -ás (Kt 88/k 713).

While this hypothesis certainly explains some cases, it does not seem to be universally valid. Several texts belonging to Peruwa's archives and bearing at least one Assyrian name show specific Anatolian features, such as lengthened vowels (Kt d/k 35b; Kt e/k 156). In another document, a loan contract owned by Peruwa and dealing with the debt of a whole village ( $\mathrm{Kt} \mathrm{d} / \mathrm{k} 28$ ), a certain Aššr-idī completes the roster of witnesses, but the scribe used some Anatolian word endings (e.g. makrēš).

Some contracts were nicely written with very few mistakes, and it is plausible that Assyrian scribes were paid by some Anatolian families to produce their contracts in accordance with Anatolian customs. Moreover, all contracts supervised by the local ruler may have been written by an official scribe, perhaps an Assyrian ${ }^{46}$ However, it is clear that some Anatolians learned the Old Assyrian dialect and cuneiform script in order to be able to write simple documents on their own.

4.3. How did Anatolians learn to speak, read and write the Old Assyrian dialect?

To answer this question, one must distinguish between language and writing, as did the inhabitants of Kaniš : the scribe, DUB.SAR, wrote tablets while the targumannum acted as translator. The existence of a 'chief of the translators' (rabi targumannē) indicates that translators worked predominantly for the administration in the context of com-

45 See also Balkan (1957: 18-30) about the language of the letter and figs. 1-6 for the ductus.

46 A list of these iqqāte tablets can be found in Kryszat (2008b: 161-165). See also Veenhof (2008a: $46-50)$. 
mercial and diplomatic relations between the local palace and the Assyrians or other foreigners (Ulshöfer 2000). Further, Anatolian merchants learned enough of the Old Assyrian dialect, and Assyrians knew some Hittite words (used in some texts), so that the two communities were able to communicate. Some Assyrians married Anatolian women (Michel 2008b), while Assyrian widows occasionally married Anatolians, and communication between such couples was presumably no problem, the children of such unions being exposed to both languages, so that the succeeding generation would have been bilingual.

Writing marked a second step. The study of the Old Assyrian school texts and scholarly production found at Kaniš and Aššur has led to an understanding of how the Assyrians learned to read and to write. Since the syllabary was quite limited - some 150 signs, consisting mostly of syllables along with a few logograms - many Assyrians were able to read and write their own contracts and letters. ${ }^{47}$ About ten Old Assyrian school texts from Kaniš are extant, all of them found in houses inhabited by Assyrians, while the case of a list of proper names (Kt 00/k 12) is less clear. Eight documents belonging to the same archive as the list have recently been published, i.e. a tablet dealing only with Anatolians ( $\mathrm{Kt} 00 / \mathrm{k} 1$ ), two treaties between Assyrian and Anatolian authorities dated to level $\mathrm{Ib}(\mathrm{Kt} 00 / \mathrm{k} 6$ and Kt $00 / \mathrm{k} 10)$, three Assyrian legal texts $(00 / \mathrm{k} 7,14,16)$ and one letter belonging to Assyrians (Kt 00/k 17). ${ }^{48}$ Again, these documents would appear to have belonged to an Assyrian archive. One can therefore conclude that none of the Old Assyrian school texts have been found in an Anatolian archive. ${ }^{49}$ As for the language, one can imagine that some educated Assyrian men who were married to Anatolian women could have taught their wives and children the basics of cuneiform writing (Michel 2009). The process would perhaps have taken longer than a normal scribal education, however, since Anatolians had first to learn the Old Assyrian dialect before being able to read and write it.

The few Anatolian archives excavated at Kaniš consist predominantly of loans and sale contracts. They suggest that some Anatolians adopted the cuneiform script and the Old Assyrian dialect. These archives belonged to wealthy individuals, such as Peruwa, the chief shepherd, who was able to accumulate enough wealth to buy a whole village. The data provided by these documents concern mainly the Anatolian elite that traded with the Assyrians. Documents written by Anatolians show characteristic features, such as mistakes with feminine and masculine suffixes and the addition of nominal case endings to Anatolian names, which were often omitted by the Assyrians.

Anatolians had first to learn the Old Assyrian dialect before they could read and write it. Acquiring this knowledge took some time, and we have quite a few Anatolian archives for the best documented years of kārum level II. An increase of mixed marriages could

47 Michel (2008a). Among these are two small exercise tablets with arithmetic problems unearthed in 1948 and 1984 (Kt a/k 178 and Kt 84/k 3), which would also have belonged to Assyrian archives.

48 Donbaz (2004b); Günbattı (2004).

49 If any such documents exist, they are still unpublished. 
have facilitated access to the Assyrian language and writing among Anatolians, and in fact, there are far more Anatolian archives in proportion from kārum level Ib than from level II.

Anatolian words are found in documents in the Old Assyrian dialect belonging to both Assyrians and Anatolians, and there is no question that it would have been possible to write down the native language spoken in Kaniš during the kārum period (Dercksen 2007). Moreover, the existence of about fifty titles of Anatolian officials, most of them borrowed into Akkadian and employed in the form rabi plus a substantive, witnesses a highly structured administration in which each economic sector was represented (Michel 2011a). Anatolians did not adapt the cuneiform script to their own language, even though it could have provided an efficient tool in their highly structured administration and complex society. Instead, Akkadian retained its prestige, serving not only diplomatic purposes but also, even if only sparingly, in the local administration, as suggested by a list of Anatölian persons found on the citadel (Bilgiç 1964; Günbattı 1987).

\section{Bibliographie}

The abbreviations used in this article follow:

- OAAS 1 = C. Michel, Old Assyrian Bibliography of Cuneiform Texts, Bullae, Seals and the Results of the Excavations at Assur, Kültepe/Kanis, Acemhöyük, Alishar and Bogazköy, Old Assyrian Archives Studies 1, Publications de l'Institut historique-archéologique néerlandais de Stamboul, vol. XCVII, Leiden, 2003.

- OAB 1 = C. Michel, Old Assyrian Bibliography 1 (February 2003-July 2006), Afo 51, 2006, 436-449.

- OAB 2 = C. Michel, Old Assyrian Bibliography 2 (July 2006-April 2009), AfO 52, 2011, 396-417.

Albayrak, İ. 1998. Koloni Çağında Yerli Bir Bayan "Madawada", 3.Uluslararası Hititoloji Kongresi Bildirileri, Çorum, 1-14.

Albayrak, İ. 2004. 'She will live, eat and be anointed together with them'. Ušbat aklat u paššat ištišunu, in J. G. Dercksen (ed.), Assyrian and Beyond. Studies Presented to Mogens Trolle Larsen, PIHANS 100, Leiden, 9-20.

Albayrak, İ. 2005. Fünf Urkunden aus dem Archiv von Peruwa, Sohn von Šuppibra, JEOL 39, 95-105.

Albayrak, I. 2007. Eine altassyrische Urkunde zum anatolischen Bodenrecht, AoF 34, 219-224.

Balkan, K. 1955. Observations on the Chronological Problems of the Kärum Kaniš, TTKY VII/28, Ankara.

Balkan, K. 1967. Contributions to the Understanding of the Idiom of the Old Assyrian Merchants of Kanish, Or 36, 393-415.

Balkan, K. 1974. Cancellation of Debts in Cappadocian Tablets from Kültepe, in Anatolian Studies Presented to Hans Gustav Güterbock on the Occasion of his $65^{\text {th }}$ Birthday, PIHANS 35, Istanbul, 29-42.

Balkan, K. 1979. Makriš and Ašiš, Component-parts of Wagons and Ploughs Respectively, in a Cappadocian Tablet from Kültepe, in Florilegium Anatolicum. Mélanges offerts à Emmanuel Laroche, Paris, $49-58$.

Bilgiç, E. 1964. Three Tablets from the City Mound of Kültepe, Anatolia 8, 145-163.

Cayır, M. 2004. Kültepe'den yerli bir tüccara ait beş tablet, $\operatorname{ArAn} 7,45-57$.

Dercksen, J. G. 2002. Kultureller und wirtschaftlicher Austausch zwischen Assyrern und Anatoliern (Anfang des zweiten Jahrtausends v. Chr.), in H. Blum, B. Faist, P. Pfälzner \& A.-M. Wittke (eds.), Brückenland Anatolien? Ursachen, Extensität und Modi des Kulturaustausches zwischen Anatolien und seinen Nachbarn, Tübingen, 35-43.

Dercksen, J. G. 2004. Some elements of Old Anatolian society in Kanis, in J. G. Dercksen (ed.), Assyria and Beyond. Studies Presented to Mogens Trolle Larsen, PIHANS 100, Leiden, 137-178. 
Dercksen, J. G. 2007. On Anatolian Loanwords in Akkadian Texts from Kültepe, ZA 97, 26-46.

Dercksen, J. G. 2008. Observations on Land Use and Agriculture in Kaneš, in C. Michel (ed.), Old Assyrian Studies in Memory of Paul Garelli, OAAS 4, PIHANS 112, Leiden, 139 157.

Donbaz, V. 1988. The Business of Ašè d, an Anatolian Merchant, AfO 35, 48-63.

Donbaz, V. 1989. Some Remarkable Contracts of 1-B Period Kültepe-Tablets, in K. Emre, B. Hrouda, M. J. Mellink \& N. Özgüç (eds.), Anatolia and the Ancient Near East. Studies in Honour of Tahsin Özgüç, Ankara, 75-98.

Donbaz, V. 1990. Kültepe 1-B Katı Tabletlerine Genel Bakış, TTK 10, Ankara, 433-451.

Donbaz, V. 1993. Some Remarkable Contracts of 1-B Period Kültepe Tablets II, in M. J. Mellink, E. Porada \& T. Özgüç (eds.), Aspects of Art and Iconography: Anatolia and its Neighbours. Studies in Honour of Nimet Özgüç, Ankara, 131-154.

Donbaz, V. 1998. Tablets from the Palace of Waršuma, in H. Erkanal, V. Donbaz \& A. Uğuroğlu (eds.), XXXIV Uluslararașı Assiriyoloji Kongresi (Istanbul 1987), TTKY XXVI/3, Ankara, 413-419.

Donbaz, V. 1999. One 1-B Kültepe Text Concerning Onions, in H. Klengel \& J. Renger (eds.), Landwirtschaft im Alten Orient, Berlin, 149-153.

Donbaz, V. 2001. Some Recently Discovered kärum 1.b Tablets and Related Observations, in G. Wilhelm (ed.), Akten des IV. Internationalen Kongresses für Hethitologie, StBoT 45, Wiesbaden, $106-114$.

Donbaz, V. 2004a. Some Remarkable Contracts of 1-B Period Kültepe Tablets III, in D. Groddek \& S. Rößle (eds.), Šarnikzel. Hethitologische Studien zum Gedenken an Emil Orgetorix Forrer, Dresdner Beiträge zur Hethitologie 10, Dresden, 271-284.

Donbaz, V. 2004b. Some Old Assyrian texts with rare terminology, in J. G. Dercksen (ed.), Assyria and Beyond. Studies Presented to Mogens Trolle Larsen, PIHANS C, Leiden, 179-190.

Donbaz, V. 2008. The Archives of Eddin-Aššur son of Ahiaya, in C. Michel (ed.), Old Assyrian Studies in Memory of Paul Garelli, OAAS 4, PIHANS 112, Leiden, 47-62.

Eisser, G. \& Lewy, J. 1930/1935. Die altassyrischen Rechtsurkunden vom Kültepe, MVAG 33 \& MVAG 35. Esen, I. 2001. 1953 Yılı Kültepe Kazılarında Bulunmuș Olan Bir Grup Vesika 2, Anadolu Medeniyetleri Müzesi Yıllı̆̆ 2000, Ankara, 194-214.

Esen, İ. 2002. 1953 Yllı Kültepe Kazılarında Bulunmuş Olan Bir Grup Vesika 3, Anadolu Medeniyetleri Müzesi Ylllı̆̆ 2001, Ankara, 257-264.

Günbattı, C. 1987. Yeniden İşlenen Bir Kültepe Tableti (Kt g/t 42+ z/t 11), Belleten 51,1-10.

Günbatt, C. 2004. Two treaty texts found at Kültcpe, in J. G. Dercksen (ed.), Assyria and Beyond. Studies Presented to Mogens Trolle Larsen, PIHANS C, Leiden, 249-268.

Günbattı, C. 2005. 2000 ve 2001 Yılı Kültepe Kazılannda Ele Geçen Bazı I-b Tabletleri, 5.Uluslararast Hititoloji Kongresi Bildirileri, Çorum 2002, Ankara, 445-451.

Günbattı, C. 2008. An Eponym List (KEL G) from Kültepe, $A o F$ 35, 103-132.

Hrozný, B. 1927. Rapport préliminaire sur les fouilles tchécoslovaques de Kültepe, Syria 8,1-12.

Kienast, B. 1984. Das altassyrische Kaufvertragsrecht, FAOS Beiheft 1, Wiesbaden/Stuttgart.

Kryszat, G. 2008a. The use of writing among the Anatolians, in J. G. Dercksen (ed.), Anatolia and the Jazira during the Old Assyrian Period, OAAS 3, PIHANS 111, Leiden, 231-238.

Kryszat, G. 2008b. Herrscher, Kult und Kulttradition in Anatolien nach den Quellen aus den altassyrischen Handelskolonien - Teil 3/1: Grundlagen für eine neue Rekonstruktion der Geschichte Anatoliens und der assyrischen Handelskolonien in spätaltassyrischer Zeit, AoF 35, 156-189.

Kulakoğlu, F. 2010. Kültepe-Kanesh Kārum: The Earliest International Trade Center in Anatolia, in F. Kulakoğlu \& S. Kangal (ed.), Anatolia's Prologue. Kültepe Kanesh Karum, Assyrians in Istanbul, Kayseri Metropolitan Municipality Cultural Publication No: 78, Istanbul, 40-51.

Larsen, M. T. 2008. Archives and Filing Systems at Kültepe, in C. Michel (ed.), Old Assyrian Studies in Memory of Paul Garelli, OAAS 4, PIHANS 112, Leiden, 77-88.

Michel, C. 1997. Les malheurs de Kunnanīya, femme de marchand, Archivum Anatolicum 3, 239-253.

Michel, C. 1998. Quelques réflexions sur les archives récentes de Kültepe, in S. Alp and A. Süel (ed.), III.Uluslararası Hititoloji Kongresi, Çorum, 1996, Ankara, 419-433.

Michel, C. 2003. Old Assyrian Bibliography of Cuneiform Texts, Bullae, Seals and the Results of the 
Excavations at Assur, Kültepe/Kanis, Acemhöyük, Alishar and Bogazköy, OAAS 1, PIHANS 97, Leiden.

Michel, C. 2006. Old Assyrian Bibliography 1 (February 2003-July 2006), AfO 51, 436-449 (OAB 1).

Michel, C. 2008a. Écrire et compter chez les marchands assyriens du début du II millénaire av. J.-C., in

T. Tarhan, A. Tibet \& E. Konyar (eds.), Muhibbe Darga Armağanı, Istanbul, Sadberk Hanım Müzesi, 345-364.

Michel, C. 2008b. Les Assyriens et leurs femmes anatoliennes, in J. G. Dercksen (ed.), Anatolia and the Jazira during the Old Assyrian Period, OAAS 3, PIHANS 111, Leiden, 209-229.

Michel, C. 2008c. The Alāhum and Aššur-taklāku archives found in 1993 at Kültepe Kaniš, in G. Kryszat (ed.), Festschrift für Karl Hecker zum 75. Geburtstag am 25. Juli 2008, AoF 35, 53-67 [abstract: AoF 35, 359].

Michel, C. 2009. Les femmes et l'écrit dans les archives paléo-assyriennes (XIX ${ }^{\mathrm{e}}$ s. av.J.-C.), in F. BriquelChatonnet, S. Fares, B. Lion and C. Michel (ed.), Femmes, cultures et sociétés dans les civilisations méditerranéennes et proches-orientales de l'Antiquité, Topoi, Suppl.10,253-272.

Michel, C. 2010a. The Day Unit within the Old Assyrian Calendar, in Ş. Dönmez (ed.), Veysel Donbaz'a Sunulan Yazalar. DUB.SAR:E.DUB.BA.A, Studies Presented in Honour of Veysel Donbaz, Istanbul, 217-224.

Michel, C. 2010b. Les comptoirs de commerce assyriens en Anatolie: emprunts réciproques et acculturation, in P. Rouillard (ed.), Portraits de migrants, portraits de colons II, Colloques de la Maison RenéGinouvès 6, Paris, 1-12.

Michel, C. 2011a. The Kārum Period on the Plateau, in S. R. Steadman and G. McMahon (eds.), Oxford Handbook of Anatolian Studies (8000-323 BCE), Oxford: Oxford University Press, 313-336.

Michel, C. 2011b. Old Assyrian Bibliography 2(July 2006-April 2009), AfO 52, 396-417 (OAB 2).

Özgüç, N. 1953. 1951 Yılında Kültepe'de Yapılan Kazı Hakkında ön Rapor [Preliminary Report on the 1951 Excavations at Kuiltepe], Belleten 17, 289-297 [298-306].

Özgüç, N. 1965. Kültepe Mühür Baskilarında Anadolu Grubu/The Anatolian Group of Cylinder Seal Impressions from Kültepe, TTKY V/22, Ankara.

Özgüç, N. 2006. Kültepe-Kaniš / Neša. Yerli Peruwa ve Aššur-imitti’nin oğlu Assur'lu Tüccar Ușur-šaIštar'ın Arişivlerine ait Kil Zarfların Mühür Baskaları / Seal Impressions on the Clay Envelopes from the Archives of the Native Peruwa and Assyrian Trader Ușur-ša-Ištar son of Aššur-imitț̄, TTKY V/50, Ankara.

Özgüç, T. 1950. Türk Tarih Kurumu Tarafindan Yapılan Kültepe Kazısı Raporu 1948 (Ausgrabungen im Kültepe),TTKY V/10, Ankara.

Özgüç,T.1953. Kültepe Kazısı Raporu 1949 (Ausgrabungen im Kültepe), TTKY V/12, Ankara.

Özgüç, T. 1959. Kültepe-Kaniş. New Researches at the Center of the Assyrian Trade colonies, TTKY V/19, Ankara.

Özgüç,T. 1964. The Art and Architecture of Ancient Kanish, Anatolia 8,27-48.

Özgüç, T. 1986. Kültepe-Kaniş. II, Eski Yakındoğu'nun Ticaret Merkezinde Yeni Araştırmalar (New Researches at the Trading Center of the Ancient Near East),TTKY V/41, Ankara.

Özgüç,T. 1999. The Palaces and Temples of Kültepe-Kaniš/Neša, TTKY V/46, Ankara.

Özgüç, T. 2003. Kültepe Kaniš/Neša. The earliest international trade center and the oldest capital city of the Hittites, The Middle Eastern Culture Center in Japan, Istanbul.

Ulshöfer, A. 2000. Sprachbarrieren und ihre Überwindung:Translatorisches Handeln im Alten Orient, in L. Milano (ed.), Landscapes, Territories, Frontiers and Horizons in the Ancient Near East. Papers Presented to the $X L I V^{\text {th }}$ Rencontre Assyriologique Internationale Venezia, 7-11 July, 1997, History of the Ancient Near East / Monographs -3/1-3, Padua, S.A.R.G.O.N. srl, 163-169.

Veenhof, K. R. 1978. An Ancient Anatolian Money-Lender. His Loans, Securities and Debt-Slaves, in B. Hruška \& G. Komoróczy (ed.), Festschrift Lubor Matouš, Budapest, 279-311.

Veenhof, K. R. 1982. The Old Assyrian Merchants and Their Relations with the Native Population of Anatolia, in Kühne H., Nissen H. J. and Renger J., Mesopotamien und seine Nachbarn. Politische und kulturelle Wechselbeziehungen im Alten Vorderasien vom 4. bis 1. Jahrtausend v. Chr., Berliner Beiträgc zum Vorderen Orient 1, Berlin, Dietrich Reimer Verlag, 147-155. 
Veenhof, K. R. 1993. On the Identification and Implications of Some Bullæ from Acemhöyük and Kültepe, in M. J. Mellink, E. Porada and T. Özgüç (eds.), Aspects of Art and Iconography: Anatolia and its Neighbors. Studies in Honour of Nimet Özgüç, Ankara, 645-657.

Veenhof, K. R. 1997. Old Assyrian and Ancient Anatolian Evidence for the Care of the Elderly. In M.Stol \& S. P. Vlemings (ed.), The Care of the Elderly in the Ancient Near East, Studies in the History and Culture of the Ancient Near East 14. Leiden, Boston and Köln, 119-160.

Veenhof, K. R. 2003. Archives of Old Assyrian Traders from karum Kanish, in M. Brosius (ed.), Ancient Archives and Archival Traditions. Concepts of Record-Keeping in the Ancient World (Oxford Studies in Ancient Documents), 78-123.

Veenhof, K. R. 2007. The Old Assyrian List of Year Eponyms. Corrections, Additions and Chronology, NABU 2007/49.

Veenhof, K. R. 2008a. The Old Assyrian Period, in: M. Wäfler (ed.), Mesopotamia. The Old Assyrian Period. Annäherungen 5. Orbis Biblicus et Orientalis 160/5, Fribourg-Göttingen, Teil 1,13-264.

Veenhof, K. R. 2008b. Some displaced Tablets from Kārum Kanesh (Kültepe), AoF 35, 10-27.

Dr. Michel, Cécile

Directrice de Recherche au CNRS

ArScAn - HAROC, UMR 7041

Maison de l'Archéologie et de l'Ethnologie

21 allée de l'Université

F - 92023 NANTERRE Cedex

cecile.michel@mae.cnrs.fr 